„Bohemistyka” 2021, nr 1, ISSN 1642-9893

Lucie RADKOVÁ

DOI: $10.14746 /$ bo.2021.1.1

Michal MísTECKÝ

Ostravská univerzita

\section{Words of Warfare: Life of Mission Soldiers in the Perspective of Quantitative Linguistics ${ }^{1}$}

Keywords: stylometry; keyword analysis; collocation analysis; military speech; Czech language

\section{Abstract}

The paper focuses on the analysis of a sample of military language from the stylometric perspective. The corpus is the chronicle of the 8th Czech Armed Forces Guard Company, which operated at the Bagram Air Field base (BAF). We work on the assumptions that in the corpus, there will be (A) a prominent presence of military slang; (B) a high proportion of abbreviations; (C) frequent linguistic devices expressing mutuality and collectiveness of the soldiers' enterprise. The texts were subjected to keyword and collocation analyses; these determined several stylistic features of theirs (such as use of English-based expressions, protocol-like language, or idiosyncratic collocations), which testify to the multifaceted character of the military chronicle genre.

\section{Introduction}

The goal of the paper is keyword and collocation analyses of military language, which will be exemplified upon the chronicle of the $8^{\text {th }}$ Czech Armed Forces Guard Company at Bagram Air Field (BAF). The company was in function from April to October 2017, and its mission was part of the Resolute Support operation. Their main task was

${ }^{1}$ The paper is part of the grant project SGS05/FF/2020 Mluva účastniků zahraničnich armádních misí (Language Devices of the Participants in Military Missions Abroad). to secure the northern part of the BAF security zone with the objective to avert inimical activities focused on BAF.

As military language has been only occasionally studied in general (Chaloupský 2005; Disler 2008; Taylor 2010; Footitt, Kelly 2012; Kelly, Baker 2013; Olagunju 2014; Mádrová 2020), the main intention of this paper is to sketch its basic stylistic features on the grounds of the aforementioned quantitative investigations. We presuppose the following characteristics of the studied corpus:

(A) a high degree of expressions linked to mostly hermetic military slang;

(B) a high proportion of abbreviations;

(C) occurrence of expressions of mutuality and solidarity (e.g., using the first-person plural, possessive pronouns, etc.).

The findings presented in the article may be of use for experts on stylistics, but also for those who would like to penetrate into the mostly classified sphere of military language. Our analyses may also provide impetuses for psychology, sociology, and various disciplines dealing with deployed soldiers.

\section{Methods and Material}

As already mentioned, the corpus is formed by the chronicle of the given guard company, which was kept by the chaplain of the unit. The chronicle is written for the leader of the guard company, and it contains full names of the mission participants and their functions; it is a private material, which the soldiers can be provided with on their request.

The text was divided into 35 parts, which respect the original chapters (e.g., "End of Mission is to Come", etc.); sometimes, very short chapters forming a logical whole were merged (e.g., "Extraordinary Incidents"). Despite the name, the chronicle does not keep a strict timeline - most places focus on various elements of soldiers' life at the airfield (e.g., "Workshop", "Patrols", "Humint Team", "Shooting Contest", "A Memorial for a Lost Friend", etc.), with the narrative being framed by the start and the end of the mission. 
Unlike the chronicle, the corpus does not contain the main headlines of the chapters, visual material and its description, authors of the quotes (including people who were supposed to append their signatures at respective places), and the author of the chronicle and his personal data. What was not excluded were subheadlines - as they mostly form questions that are part of the text -, notes on the authors of the individual passages, auto-questions in interviews, and quotes.

The quantitative characteristics of the corpus are given in Table 1. The lemmatization was carried out by the QUITA(Quantitative Index Text Analyser) software, which was also used for detecting thematic words (see further; Kubát et al. 2014).

Table 1. Characteristics of the studied corpus

\begin{tabular}{||l|l|}
\hline Tokens & 9,393 \\
\hline Types & 3,688 \\
\hline Lemmata & 2,544 \\
\hline
\end{tabular}

As for methods, keyword analysis will be carried out via the KWords software (see the References section), developed by the Czech National Corpus. It is based upon the comparison of the frequencies of the wordform in a studied corpus ("target corpus") and in a pre-selected reference set of texts. For the sake of our analysis, we chose SYN2015 as our reference corpus - it is a body of written Czech including texts mostly from the period of 2010-2014. The texts come from the spheres of fiction, academia, textbooks, and opinion journalism (Křen et al. 2016).

The level of significance was set at 0.001 , the minimal frequency of the wordform in the target corpus to be 5 . We focused on autosemantic words only, excluding pronouns, numerals, prepositions, conjunctions, and interjections from the scope of the research. The level of "keywordness" was stated according to the Difference Index (DIN), the formula of which is as follows -

\section{DIN $=100 \times \frac{f_{r}(\operatorname{targ})-f_{r}(\text { ref })}{f_{r}(\operatorname{targ})+f_{r}(r e f)}$}

$f_{r}$ (targ) stands for the frequency of the wordform in the military corpus (= target corpus), and $f_{r}$ (ref) for the same in the SYN2015 corpus. In the investigation, only words with $D I N>0.98$ were taken into account.

Next, the studied texts were analysed as to the collocations of selected lemmata, which were determined on the grounds of their position in the rank-frequency distribution of the corpus vocabulary. This distribution (for the first section of it, see Table 2) can be divided into two parts by h-point, which corresponds to the place where the rank of a word equals its frequency ${ }^{2}$, namely -

\section{$h=r=f(r)$}

In the military corpus, $h=34$ (in Table 2 ). ${ }^{3}$ The words used in the collocation analysis were autosemantic expressions with the frequencies higher than this value. These are also called thematic words. ${ }^{4}$

\footnotetext{
${ }^{2}$ If no such place is to be found, there is a formula to find out h-point. For more see Popescu (2007), Tuzzi et al. (2010), or Místecký (2019).

${ }^{3}$ Since we use the h-point as an auxiliary device for determination of the most frequent autosemantic expressions in the text, we have not worked with averaged ranks in the paper. If it had been so, very few words would have penetrated into the region over the h-point.

${ }^{4}$ For more on thematic words and on pitfalls of their investigation, see, e.g., Čech, Kubát (2016). Autosemantic words are those that belong to the word-classes of nouns, adjectives, and verbs, functional ones (such as "be" and "have") excluded.
} 
Table 2. The rank-frequency distribution of the military corpus

\begin{tabular}{|c|c|c|c|}
\hline Rank & Lemma & Translation & Frequency \\
\hline 1 & $\mathrm{a}$ & and & 345 \\
\hline 2 & být & be & 343 \\
\hline 3 & $\mathrm{v}$ & in & 250 \\
\hline 4 & na & on & 219 \\
\hline 5 & se & oneself & 195 \\
\hline 6 & který & who / which & 106 \\
\hline 7 & $\mathrm{~s}$ & with & 100 \\
\hline 8 & $\mathrm{z}$ & from & 97 \\
\hline 9 & ten & the / this & 95 \\
\hline 10 & základna & base & 94 \\
\hline 11 & $\mathrm{i}$ & as well as & 78 \\
\hline 12 & četa & platoon & 65 \\
\hline 13 & do & to & 55 \\
\hline 14 & pro & for & 55 \\
\hline 15 & můj & my & 53 \\
\hline 16 & baf & BAF & 49 \\
\hline 17 & voják & soldier & 48 \\
\hline 18 & SR & GC & 48 \\
\hline 19 & tým & team & 47 \\
\hline 20 & mít & have & 47 \\
\hline 21 & $\mathrm{k}$ & towards & 46 \\
\hline 22 & úkol & task & 45 \\
\hline 23 & velitel & commander & 45 \\
\hline 24 & tento & this / this one & 43 \\
\hline 25 & on & he & 43 \\
\hline 26 & patrola & patrol & 42 \\
\hline 27 & $\mathrm{za}$ & behind & 41 \\
\hline 28 & při & next to & 40 \\
\hline
\end{tabular}

\begin{tabular}{||l|l|l|l|}
\hline \hline 29 & př́iprava & preparation & 40 \\
\hline 30 & všechno & all & 38 \\
\hline 31 & svůj & one's own & 36 \\
\hline 32 & jeho & his & 35 \\
\hline 33 & jednotka & unit & 34 \\
\hline 34 & já & I & 34 \\
\hline 35 & že & that [conj] & 31 \\
\hline 36 & po & after [prep] & 31 \\
\hline 37 & rota & company & 30 \\
\hline 38 & tak & so & 30 \\
\hline 39 & vozidlo & vehicle & 29 \\
\hline 40 & mise & mission & 29 \\
\hline
\end{tabular}

As can be seen, there are 11 autosemantic lemmata to be found over h-point ("base", "platoon", "BAF", "soldier", "GC 6 ", "team", "task", "commander", "patrol", "preparation", "unit"). These expressions may be considered the content core that the chronicle revolves around; their collocation analysis will be based upon the Dice metric (Cvrček 2015), which does not take into account the size of the corpus and is not difficult for linguistic interpretation. Its formula reads -

\section{Dice $(x y)=\frac{2 f(x y)}{f(x)+f(y)}$}

$f(x)$ stands for the frequency of lemma $x, f(y)$ for the frequency of collocate $y$, and $f(x y)$ for the frequency of their co-occurrence. The minimal frequency of the collocate was determined to be 3 , and the span covers the area of $+5 /-5$. Dice scores in the interval of $\langle 0 ; 1\rangle$, the top value meaning that the lemma and the collocate always cooccur. In our

\footnotetext{
${ }^{5}$ The abbreviation for "Bagram Air Field"

${ }^{6}$ The abbreviation for "Guard Company".
} 
analysis, we focus on the Dice values over 0.2 only. The collocation analysis was carried out by the LancsBox software (Brezina et al. 2015).

\section{Keyword Analysis}

The results of the keyword analysis are presented in Table 3. The log-likelihood (LL) figure mathematicises the amount of difference in the frequencies of the given word in the two corpora. The explanation of the morphological abbreviations is given in the appendix to the study. The meanings of the abbreviated keywords are given only if they were translated into English with a different spelling. There are 55 keywords in total.

Table 3. Keywords in the studied corpus

\begin{tabular}{||l|l|c|c|c|c|}
\hline Form & Translation & LL & DIN & Fq (text) & Fq (ref) \\
\hline eaglu & Eagle [gen; dat] & 92 & 100 & 5 & 0 \\
\hline humint & Humint & 130 & 100 & 7 & 0 \\
\hline baf & BAF & 911 & 100 & 49 & 0 \\
\hline sr & GC & 892 & 100 & 48 & 0 \\
\hline zo & $\begin{array}{l}\text { FO [ [ foreign opera- } \\
\text { tion] }\end{array}$ & 92 & 100 & 5 & 0 \\
\hline rs & $\begin{array}{l}\text { RS [Resolute Sup- } \\
\text { port] }\end{array}$ & 92 & 100 & 5 & 0 \\
\hline bagrám & Bagram & 410 & 99 & 24 & 8 \\
\hline patrolách & patrols [loc] & 102 & 99 & 6 & 2 \\
\hline cimic & CIMIC & 117 & 99 & 7 & 3 \\
\hline explosive & explosive & 79 & 99 & 5 & 5 \\
\hline úkolového & task [adj, gen] & 79 & 99 & 5 & 5 \\
\hline patrol & patrols [gen] & 308 & 99 & 20 & 26 \\
\hline medevac & MEDEVAC & 75 & 99 & 5 & 8 \\
\hline
\end{tabular}

${ }^{7}$ As to the abbreviations BAF, SR, ZO, and RS, the KWords software confused them with homonymous Czech words. We have, therefore, carried out their analyses manually.

\begin{tabular}{||l|l|c|c|c|c||}
\hline \hline patroly & $\begin{array}{l}\text { patrol [gen, sg; nom, } \\
\text { pl; acc, pl] }\end{array}$ & 159 & 99 & 11 & 26 \\
\hline ačr & $\begin{array}{l}\text { ACR [ [ Army of the } \\
\text { Czzech Republic] }\end{array}$ & 115 & 99 & 8 & 20 \\
\hline ied & IED & 122 & 99 & 9 & 36 \\
\hline scan & scan & 216 & 99 & 16 & 66 \\
\hline průzkumného & $\begin{array}{l}\text { exploratory [masc, } \\
\text { gen] }\end{array}$ & 118 & 99 & 9 & 44 \\
\hline strážních & guard [adj, gen, pl] & 101 & 99 & 8 & 54 \\
\hline obvaziště & dressing station & 73 & 99 & 6 & 49 \\
\hline tlumočníci & interpreters & 58 & 99 & 5 & 53 \\
\hline čet & platoons [gen] & 199 & 99 & 17 & 185 \\
\hline eagle & Eagle & 126 & 99 & 11 & 134 \\
\hline četař & platoon sergeant & 79 & 99 & 7 & 90 \\
\hline četě & platoon [dat] & 77 & 99 & 7 & 105 \\
\hline základně & base [dat] & 407 & 99 & 37 & 581 \\
\hline čety & $\begin{array}{l}\text { platoon [gen, sg; } \\
\text { nom, pl; acc, pl] }\end{array}$ & 261 & 99 & 24 & 399 \\
\hline incidenty & incidents & 52 & 99 & 5 & 105 \\
\hline army & army & 52 & 99 & 5 & 107 \\
\hline roty & $\begin{array}{l}\text { company [gen, sg; } \\
\text { nom, pl; acc, pl] }\end{array}$ & 258 & 99 & 25 & 551 \\
\hline četu & platoon [acc] & 51 & 99 & 5 & 117 \\
\hline zdravotník & medic & 59 & 99 & 6 & 164 \\
\hline základny & $\begin{array}{l}\text { base [gen, sg; nom, } \\
\text { pl; acc, pl] }\end{array}$ & 331 & 99 & 34 & 1029 \\
\hline strážní & $\begin{array}{l}\text { guard [adj, fem - } \\
\text { gen, sg; dat, sg; acc, } \\
\text { sg; loc, sg; instr, sg; } \\
\text { nom, pl; acc, pl] }\end{array}$ & 184 & 99 & 19 & 587 \\
\hline cvičili & $\begin{array}{l}\text { trained [3 } 3 \text { rd person, } \\
\text { pl] }\end{array}$ & 48 & 99 & 5 & 156 \\
\hline kábulu & Kabul [gen; dat; loc] & 47 & 99 & 5 & 177 \\
\hline nováčků & novices [gen] & 45 & 99 & 5 & 213 \\
\hline koaličních & $\begin{array}{l}\text { Coalition [adj - gen, } \\
\text { pl] }\end{array}$ & 63 & 99 & 7 & 303 \\
\hline
\end{tabular}




\begin{tabular}{||l|l|c|c|c|c||}
\hline \hline praporu & battalion [gen; dat] & 98 & 99 & 11 & 485 \\
\hline elektronického & electronic [gen] & 88 & 99 & 10 & 476 \\
\hline četa & platoon & 43 & 99 & 5 & 247 \\
\hline misi & $\begin{array}{l}\text { mission [dat; acc; } \\
\text { loc] }\end{array}$ & 113 & 99 & 13 & 654 \\
\hline základnu & base [acc] & 133 & 98 & 16 & 989 \\
\hline střelnici & $\begin{array}{l}\text { firing range [dat; } \\
\text { acc; loc] }\end{array}$ & 40 & 98 & 5 & 331 \\
\hline afghánistánu & $\begin{array}{l}\text { Afghanistan [gen, } \\
\text { loc] }\end{array}$ & 146 & 98 & 18 & 1224 \\
\hline rotace & rotation & 47 & 98 & 6 & 452 \\
\hline výcvik & training & 103 & 98 & 13 & 988 \\
\hline zpravodajské & $\begin{array}{l}\text { intelligence [adj, fem } \\
\text { ngen, sg; dat, sg; } \\
\text { nom, pl; acc, pl] }\end{array}$ & 55 & 98 & 7 & 543 \\
\hline specialista & specialist & 62 & 98 & 8 & 638 \\
\hline velitele & $\begin{array}{l}\text { commander [gen; } \\
\text { acc] }\end{array}$ & 116 & 98 & 15 & 1243 \\
\hline veliteli & commander [dat] & 53 & 98 & 7 & 615 \\
\hline mise & mission & 98 & 98 & 13 & 1181 \\
\hline zraněných & $\begin{array}{l}\text { wounded [noun- } \\
\text { gen, pl] }\end{array}$ & 37 & 98 & 5 & 478 \\
\hline prostějova & Prostějov [gen] & 37 & 98 & 5 & 483 \\
\hline výcviku & $\begin{array}{l}\text { training [gen; dat; } \\
\text { loc] }\end{array}$ & 57 & 98 & 8 & 869 \\
\hline
\end{tabular}

As can inferred from the list, most of the vocabulary focuses on the everyday life of the military personnel ("training", "rotation", "base", "mission", etc.), with a special attention paid to the people who form the unit ("commander", "medic", "company", "platoon sergeant", "interpreters", etc.), whose work and duties are extensively presented in the chronicle. This corresponds to its character, as indicated in Part 2 . The used vocabulary is, in general, understandable even to outsiders, and the chronicle does not seem to overemploy impenetrable military slang. This can also be connected to the fact that the chronicle serves for the leader of the company, who needs a general outline of the events and activities only.
Linguistically, the assumption concerning the prominence of abbreviations seems a sound one, as they make important appearances among the keywords ( 8 out of 55, i.e. $15 \%$ ); some of these may not be easily decipherable for a casual user of language (e.g., "CIMIC", "RS", "ZO", "IED"), some others may have been spotted in journalism texts ("MEDEVAC", "AČR"). ${ }^{8}$ It seems that use of abbreviations forms the stylistic backbone of the chronicle, as they are generally well-known among the soldiers, speed up the communication process, and may also create a bond among those who understand them. The same conclusions were made during the research of the specific vocabulary used in an elite police unit which focuses on investigating corruption and financial crime (cf. Radková 2018).

Despite this, some of the abbreviations need to be explained in the text, too (see example 1). Sometimes, they even prove productive in Czech and form new words (see example 2).

[1]

Another specialist of the $8^{\text {th }} \mathrm{GC}$ BAF is the EOD (Explosive Ordnance Disposal), which is also called CIED (Country Improvized Explosive Devices). It is an expert on explosives of the IED type (Improvized Explosive Devices) ${ }^{9}$

[2]

An inseparable part of the $8^{\text {th }} \mathrm{GC}$ BAF is an operative of civil military cooperation, abbreviated as CIMIC (Civil Military Cooperation). As the name implies, the workload of a "Cimicker" is to establish and keep good relations and cooperation with the local civil population. ${ }^{10}$

\footnotetext{
${ }^{8}$ As to the use of abbreviations in military slang, see Taylor (2010).

${ }^{9}$ Dalším odborníkem 8. SR BAF je specialista EOD (Explosive Ordnance Disposal) označovaný také CIED (Country Improvized Explosive Devices). Je to znalec přes výbušniny a nástražné výbušné systémy IED (Improvized Explosive Devices).

${ }^{10}$ Nedílnou součástí 8 . SR BAF je pracovník civilně-vojenské spolupráce, zkráceně CIMIC (Civil Military Cooperation). Jak z názvu vyplývá, pracovní náplní „cimikáŕe“ je navazovat a udržovat dobré vztahy a spolupráci s místním civilním obyvatelstvem.
} 
What is connected to the use of abbreviations, but forms a separate field of study, is the employment of the English-origin expressions (anglicisms). The very workings of the mission seems to have been formatted upon the system used in the US Army. Some of the expressions (especially concerning daily duties, see examples 3 and 4) are translated (or paraphrased) into Czech, some are not; both the reasons are why some English or English-like words ("Eagle", "Humint", "explosive", "scan") penetrated into the list of the keywords. Dealing with anglicisms is thus very varied, as is testified to by the following examples; however, in most cases, after the term is explained, preference is given to the English expression (see examples 5 and 6)

[3]

Before each departure of the platoon on a patrol off the base, the intelligence officer carries out poučení (Patrol Rebrief). [...] After comeback from the patrol, s/he meets the platoon and carries out its informačni vytěžení (Patrol Debrief). ${ }^{11}$

[4]

$[\ldots]$ the exact identification of the cause of the threats (Targetting). ${ }^{12}$

[5]

In order to achieve the aforementioned goals, the ISR unit has three means. The first and the most important means is human resources intelligence (HUMINT) [...]. The HUMINT team (Human Intelligence) fulfils the objectives of human resources intelligence in favour of the decision process of the commander. ${ }^{13}$

[6]

Scan Eagle is able to fly, day or night, up to 24 hours non-stop. [...] The

${ }^{11}$ Před každým výjezdem čety na patrolu mimo základnu zpravodajec provede poučení (Patrol Prebrief). [...] Po návratu z patroly se opět s četou sejde a provede její informační vytěžení (Patrol Debrief).

${ }^{12}$, ,[...] přesné určené původce hrozeb” (Targetting).

${ }^{13}$ Jednotka ISR má k naplnění výše zmíněných činností tři prostředky. Prvním a nejdůležitějším prostředkem, je zpravodajství z lidských zdrojů (HUMINT) [...] Tým HUMINT (Human Intelligence) provádí úkoly zpravodajství z lidských zdrojů ve prospěch rozhodovacího procesu velitele. members of Scan Eagle can cover for each other in their functions, if needed. $[\ldots]$ The greatest enemy of the Scan Eagle team is strong wind. ${ }^{14}$

As to the $\mathrm{C}$ assumption, generally, verbs did not occur prominently in the keyword analysis (except for the past tense "[they] trained" and the past participle "wounded"); no expressions of mutuality have thus been detected. It is probable that the forthcoming collocation analysis will shed more light upon the situation in this respect.

\section{Collocation Analysis}

The collocation analysis has been carried out on the grounds of the aforementioned principles. Moreover, the synsemantic collocates (i.e., prepositions, conjunctions, and particles), altogether with some two-word groupings, which the programme determined faultily (e.g., "z čety" - "from-platoon"), have been excluded from the research. As to pronouns, only personal and possessive ones were investigated, as they are connected to assumption $\mathrm{C}$ (see Part 1). The results are presented in Table 4.

Table 4. Collocation analysis of the military corpus

\begin{tabular}{|l|l|l|l|l|l|l|c||}
\hline \hline Lemma & $\begin{array}{l}\text { Transla- } \\
\text { tion }\end{array}$ & $\begin{array}{l}\text { Posi- } \\
\text { tion }\end{array}$ & $\begin{array}{l}\text { Collo- } \\
\text { cate }\end{array}$ & Translation & Dice & $\begin{array}{l}\text { Fq } \\
\text { (coll) }\end{array}$ & $\begin{array}{l}\text { Fq } \\
\text { (corp) }\end{array}$ \\
\hline BAF & BAF & L & SR & GC & 1.00 & 46 & $44^{15}$ \\
\hline SR & GC & R & BAF & BAF & 1.00 & 46 & 48 \\
\hline
\end{tabular}

${ }^{14}$ Scan Eagle je schopen létat ve dne i v noci až 24 hodin bez mezipřistání. [...] Členové Scan Eaglu se $\mathrm{v}$ př́padě potřeby na svých funkcích zastupují. [...] Největším nepř́itelem týmu Scan Eagle je silný vítr.

${ }^{15}$ This seemingly paradoxical situation has been caused by the fact that at two places in the text, the lemma "BAF" collocates, within the given span, with two occurrences of "GC".

"Who is the $8^{\text {th }}$ GC BAF? - The $8^{\text {th }}$ GC BAF is 159 soldiers (...)"

"(...) official handing over of the operational task between the $7^{\text {th }} \mathrm{GC}$ BAF and the $8^{\text {th }}$ GC BAF."

A similar situation has brought about the unusual Dice value of the "GC - BAF" collocation (the second line of the table). 


\begin{tabular}{|c|c|c|c|c|c|c|c|}
\hline SR & GC & $\mathrm{L}$ & 8 & 8 & 0.92 & 43 & 49 \\
\hline BAF & BAF & $\mathrm{L}$ & 8 & 8 & 0.89 & 43 & 49 \\
\hline příprava & preparation & $\mathrm{L}$ & fáze & phase & 0.58 & 15 & 12 \\
\hline příprava & preparation & $\mathrm{R}$ & byla & $\begin{array}{l}\text { was } \\
{\left[3^{\text {rd }} \text { person, }\right.} \\
\text { fem }]\end{array}$ & 0.42 & 13 & 22 \\
\hline příprava & preparation & $\mathrm{L}$ & $\begin{array}{l}\text { př́ípra- } \\
\text { vy }\end{array}$ & $\begin{array}{l}\text { preparation } \\
\text { gen, sg; nom, } \\
\text { pl; acc, pl] }\end{array}$ & 0.35 & 11 & 22 \\
\hline základna & base & $\mathrm{R}$ & $\begin{array}{l}\text { Ba- } \\
\text { grám }\end{array}$ & Bagram & 0.35 & 19 & 23 \\
\hline úkol & task & $\mathrm{L}$ & plnění & fulfilment & 0.34 & 9 & 9 \\
\hline jednotka & unit & M & $\begin{array}{l}\text { jednot- } \\
\text { ky }\end{array}$ & $\begin{array}{l}\text { unit [gen, sg; } \\
\text { nom, pl; acc, } \\
\text { pl] }\end{array}$ & 0.30 & 8 & 21 \\
\hline patrola & patrol & $\mathrm{L}$ & čety & $\begin{array}{l}\text { platoon [gen, } \\
\text { sg; nom, pl; } \\
\text { acc, pl] }\end{array}$ & 0.30 & 9 & 21 \\
\hline příprava & preparation & $\mathrm{L}$ & třetí & third & 0.24 & 6 & 9 \\
\hline příprava & preparation & $\mathrm{L}$ & jsme & $\begin{array}{l}\text { are } \\
{\left[1^{\text {st }} \text { person, } \mathrm{pl}\right]}\end{array}$ & 0.24 & 9 & 36 \\
\hline tým & team & $\mathrm{R}$ & scan & scan & 0.23 & 7 & 16 \\
\hline příprava & preparation & $\mathrm{L}$ & $\begin{array}{l}\text { indivi- } \\
\text { duální }\end{array}$ & individual & 0.23 & 5 & 3 \\
\hline patrola & patrol & $\mathrm{R}$ & $\begin{array}{l}\text { základ- } \\
\text { nu }\end{array}$ & base [acc, sg] & 0.21 & 6 & 16 \\
\hline velitel & commander & $\mathrm{R}$ & SR & $\mathrm{GC}$ & 0.21 & 9 & 44 \\
\hline velitel & commander & $\mathrm{L}$ & ř́ijna & $\begin{array}{l}\text { October } \\
\text { [gen, sg] }\end{array}$ & 0.20 & 5 & 7 \\
\hline
\end{tabular}

Along with him, two other soldiers were injured, one of whom slightly. ${ }^{16}$

[8]

The soldiers of the guard platoons were acquainting themselves with their new weapons $[\ldots]^{17}$

[9]

The soldiers were taught how to navigate a helicopter and practised helicopter airdrops. ${ }^{18}$

The same logic seems to be responsible for the low-value results of the "platoon" lemma. It is linked to many collocates with the values of Dice below 0.2 (such as "our", "platoon sergeant", "guard patrol [gen, pl]", etc.), this indicating the changeable surroundings of the word (see examples 10,11, and 12). The number of collocates may also point at the various activities of the soldiers, this stressing out both their hard work, and the fact that their profession is not monotonous. This approach contrasts to the position of "preparation" (see later), which, on the other hand, collocates with activities that are strictly protocoled and do not give much space to modifications.

[10]

The guard platoon fulfils the tasks of patrolling and guarding the assigned space in the surroundings of the Bagram base. ${ }^{19}$

\section{[11]}

Since the handover of the operational task, our platoons have carried out up to eighty patrols around the base. ${ }^{20}$

[12]

The platoon members do not solve useless personal conflicts, everyone may

It is visible that 9 out of 11 thematic words participate in the top-scoring 18 collocations; one exception is "soldier", which is used with certain collocates (e.g., the past tense "[he] injured", or "a while") none of which score over 0.2 . This can be explained by the fact that "soldiers" emerge in the descriptions of various activities (incidents, trainings, etc.), which differ as to their developments, this necessitating varied vocabulary. Compare the following examples $(7,8,9)$.

\footnotetext{
${ }^{16}$ Spolu s ním byli zraněni ještě dva vojáci, z toho jeden lehce.

${ }^{17}$ Vojáci strážních čet se seznamovali s novými zbraněmi [...]

${ }^{18}$ Vojáci se učili navádět vrtulník a cvičili vrtulníkový výsadek.

${ }^{19}$ Strážní čety plní úkoly patrolování a hlídkování v přiděleném prostoru v okolí základny Bagrám.

${ }^{20}$ Od chvíle převzetí operačního úkolu naše čety provedly téměř osmdesát patrol kolem základny.
} 
lean on the experienced platoon core whenever they like, and everyone likes to put their shoulders to the wheel..$^{21}$

The strongest bond has been found in between the manifoldly treated components of collocation " 8 th $\mathrm{GC}$ BAF", which stands for the main military unit. The fact that "GC" and "BAF" are also thematic words point at the importance of the unit for soldiers' lives, and its frequent repetition in the text underlines its almost family-like character. It is to be noted that deployment is a very unusual period in a soldier's life, during which an individual acquires different values and behaviour patterns (cf. Strobl 2018). The viewpoint on the unit as the second family is also perceptible in examples 13 and 14 .

\section{[13]}

Being certain that in the gravest moments, we will be able to rely on our closest combatant."22

\section{[14]}

What I especially like about our platoon is our headquarters, which rather looks like a leadership of a group of friends, but [it is] despite this at a very professional level when approaching individual members. ${ }^{23}$

Moreover, the fact that the words denoting the guard company are abbreviations not only supports our assumption B, but it may also produce a certain magical aura connected to it.

The tendency to repeat core expressions is also visible in case of the "preparation - preparation" and "unit-unit" pairs (the Dice values of 0.35 and 0.3 , respectively). Examples 15, 16, and 17 show typical lexical repetitions, some of which even stretch over the given collocation span. An influence of the clear-cut style of military reports may have played a role in this practice, but it also indicates desire for preci-

${ }^{21}$ Př́íslušníci čety neřeší zbytečné osobní spory, kdykoliv se může každý opřít o zkušené jádro čety a každý rád přiloží ruku $\mathrm{k}$ dílu.

${ }^{22} \mathrm{~S}$ jistotou, že v těch nejtěžších chvílích se vždy budeme moct spolehnout na svého nejbližšího spolubojovníka.

${ }^{23} \mathrm{Na}$ četě se mi hlavně líbí naše velení, které spíše připomíná vedení kamarádské party, ale i přes to na velmi profesionální úrovni př́stupu k jednotlivým př́islušníkům. sion and unambiguousness. With a certain licence, it is possible to say that the meticulously planned course of the mission is paralleled, at the language level, by the exact wording of the procedure. In this perspective, it is not without surprise that "preparation" is the lemma with most collocates (6).

\section{[15]}

The second phase of preparation was focused on individual preparation of a soldier. $^{24}$

\section{[16]}

The phase of individual preparation was ended at the moment of fulfilling all objectives and launching the third phase of preparation - collective preparation of the unit. $^{25}$

\section{[17]}

Both the unit, and the headquarters participate in the training. The units also carry out instructive health trainings for the members of Afghan National Defense and Security Forces (ANDSF). ${ }^{26}$

One of the "preparation" collocates - "are" - brings us to check whether the collocation analysis has produced any expressions testifying to the importance of solidarity and mutuality in the chronicle. "Are" seems to be a solitary example of these (see example 18), but they tend to occur, scoring lower values (such as "our platoon" [0.14], "our task" [instr; 0.13], "our preparation" [0.11], "base - [we] are" [0.05], etc.; see examples 19 and 20). There is thus some presence of these expressions, but they do not notably appear with the thematic words of the text. In case of the first-person of the verb "be", it may be due to the fact that it tends to occur within the contexts of functional words, which were not in the scope of our research.

\footnotetext{
${ }^{24}$ Druhá fáze přípravy byla zaměřena na individuální přípravu vojáka.

${ }^{25}$ Fáze individuální př́ípravy byla ukončena ve chvíli splnění všech zadaných povinností a zahájením třetí fáze přípravy - společné př́pravy jednotky.

${ }^{26}$ Výcviku se účastní zejména jednotky, ale i štáb. Jednotky také provádí instruktážní zdravotní výcvik pro př́slušníky Afghánských bezpečnostních složek (ANDSF).
} 
Before the very deployment, we went through intensive preparation. ${ }^{27}$

[19]

Although our preparation was not always easy, and we struggled with many difficulties, we always did manage to solve them. ${ }^{28}$

[20]

I would say that our platoon is specific thanks to its relaxed atmosphere - it is not needed to reprimand people, as what prevails is complete self-reliance and responsibility when the tasks are fulfilled. ${ }^{29}$

Last but not least, it is of importance to check whether the collocation analysis has revealed any expressions of hermetic military slang (assumption A). Abbreviations put aside, it seems that the peaking collocations are not of the secretive nature, and though they denote the activities typical of the deployment (task fulfilment, preparation, patrolling, etc.), they do so using widely understandable lexis. ${ }^{30}$ This intelligibility may also be ascribed to the fact that many of these expressions have penetrated into journalism and became widespread especially when grave incidents happened - e.g., the phenomenon of patrolling was discussed when Czech soldiers were killed in August 2018. However, there is an essential difference in using these lexical units in the chronicle and in casual conversation - in the former, they stand for exactly defined processes, whereas in the latter, they are understood only to a certain extent.

${ }^{27}$ Před vlastním vysláním do zahraniční operace jsme absolvovali intenzivní přípravu.

28 Ačkoli naše př́íprava nebyla vždy jednoduchá a potýkali jsme se s mnoha těžkostmi, nakonec se nám je vždy podařilo vyřešit.

${ }_{29}^{2}$ Řekl bych, že naše četa je specifická uvolněnou atmosférou, kdy není potřeba jednotlivce napomínat, protože převládá naprostá samostatnost a zodpovědnost při plnění stanovených úkolů.

${ }^{30}$ For details in the function of the specific vocabulary used by deployed soldiers, see Radková - Mádrová (in the review process).

\section{Conclusions}

It has been shown that the military chronicle is an idiosyncratic genre, which can be characterized as a collection of texts written in a mixture of styles. The main outcomes of the paper will be summed up in the following points.

1) It has been manifested that assumptions A and B are mutually connected - military slang usually materializes in abbreviations, which tend to score very high in keywords and they do appear as both thematic words, and collocates ("GC", "BAF", etc.). Moreover, use of abbreviations is linked to English-origin expressions ("HUMINT", "MEDEVAC", "CIMIC", etc.), which have been proved an important feature of the studied corpus.

2) As to assumption $C$, some degree of mutuality has been detected in collocation analysis, but usually in rigid combinations of words. In case of keywords, these expressions were quasi-absent. As the chronicle is actually a patchwork of texts of different natures, it may not have been possible for this feature to surface in the frequency-based research. A more detailed analysis would be needed in this case.

3) Besides these reasonings, there are some features of the chronicle that co-define it from the stylistic and content viewpoints, namely:

a) the central position of the unit that was deployed (" 8 th $\mathrm{GC}$ BAF");

b) varied character of the texts, which is responsible for a rather low number of firm collocations - the stories alter with very official language focused on predefined routines;

c) linguistically, the tendency to show precision in fulfilling objectives is reflected in lexical repetitions, sometimes producing very unusual collocations (such as "preparation - preparation", "unit-unit").

There are many ways of developing the research further - various other stylometric indicators may be computed, more chronicles in different languages may be subjected to comparison, and the chronicle it- 
self may be compared to other texts connected to military life (e.g., soldiers' personal journals, protocols).

\section{Shortcuts}

$\begin{array}{ll}\text { acc } & \text { Accusative Case } \\ \text { adj } & \text { Adjective } \\ \text { adv } & \text { Adverb } \\ \text { conj } & \text { Conjunction } \\ \text { dat } & \text { Dative Case } \\ \text { fem } & \text { Feminine Gender } \\ \text { gen } & \text { Genitive Case } \\ \text { imp } & \text { Imperative Mood } \\ \text { instr } & \text { Instrumental Case } \\ \text { loc } & \text { Locative Case } \\ \text { masc } & \text { Masculine Gender } \\ \text { neu } & \text { Neuter Gender } \\ \text { nom } & \text { Nominative Case } \\ \text { past part } & \text { Past Participle } \\ \text { pl } & \text { Plural Number } \\ \text { prep } & \text { Preposition } \\ \text { sg } & \text { Singular Number }\end{array}$

\section{References}

B rezin a Vaclav, M c En er y Tony, W a t t a m Stephen. (2015). Collocations in context: A new perspective on collocation networks. International Journal of Corpus Linguistics, 20(2), pp. 139-173.

C v r č e k Václav. Asociační (kolokační) míry [Association (Collocation) Measures]. Available at: ttps://wiki.korpus.cz/doku.php/pojmy:asociacni_miry [quoted 20-07-21].

$\breve{C}$ e c h Radek, K u bát Miroslav. (2016). Text length and the thematic concentration of text. Mathematical Linguistics, 2, pp. 5-13.

D i s 1 e r Edith. (2008). Language and Gender in the Military: Honorifics, Narrative, and Ideology in Air Force Talk. New York: Cambria Press.

F o o t it t Harry, Ke 11y Michael. (2012). Languages and the Military (Palgrave Studies in Languages at War). New York: Palgrave Macmillan.

C h a 1 o u p s ký Ladislav. (2005). A sociolinguistic interpretation of military slang and vernacular expressions. Dissertation. Brno: Masarykova univerzita.
K elly Michael, B a k e r Catherine. (2013). Interpreting the peace: peace operations, conflict and language in Bosnia-Herzegovina. New York: Palgrave Macmillan.

Kř e n Michal, C vrč e k Václav, Ča pka Tomáš, Čer mák ová Anna, Hnát ková Milena, Chlumská Lucie, Jelínek Tomáš, Kovář́íková Dominika, P etkevi č Vladimír, Prochá zka Pavel, Sk o u malová Hana, Škrabal Michal, Truneček Petr, Vondřička Pavel, Z a s in a Adrian. (2016). SYN2015: Representative Corpus of Contemporary Written Czech, [in:] Proceedings of the Tenth International Conference on Language Resources and Evaluation (LREC'16), pp. 2522-2528. Portorož: ELRA.

K u bá t Miroslav, M a 1 a c h Vladimír, Č e c h Radek. (2014). QUITA. Quantitative Index Text Analyzer. Lüdenscheid: RAM-Verlag.

KWords. The Czech National Corpus, 2015. Available at: ttps://kwords.korpus.cz [quoted 20-07-21].

M á d r o v á Jarmila. (2020). Lexikum účastniků mezinárodnich zahraničních operaci a pozorovatelských misi (terénní výzkum) [The Lexicon of Participants in International Foreign Operations and Observation Missions (Field Research)]. MA thesis. Ostrava: Ostravská univerzita.

Mís te cký Michal. (2019). Využití rankové frekvenční distribuce při výzkumu antroponym $\mathrm{v}$ literárních dílech [Using the Rank-Frequency Distribution in Analysing Proper Names in Fiction]. Linguistica Brunensia, 67(1), pp. 27-38.

Olagunju Tosin. (2014). Language interactions between soldiers and corps members on NYSC camp. Saarbrücken: Scholar's Press.

P o p e s c u Ioan-Iovitz. (2007). The ranking by the weight of highly frequent words, [in:] Grzybek, Peter, Köhler, Reinhard (eds.). Exact Methods in the Study of Language and Text. Berlin / New York: Mouton de Gruyter, pp. 555-565.

R a d k o v á Lucie. (2018). Ráfek a cépézetka. Proč ne informátor a cela předběžného zadržení? Funkce policejní mluvy z pohledu jejích uživatelů [Ráfek ('nark') and cépézetka ('clink'). Why Not informátor ('informer') and cela předběžného zadržení ('police cell')? The Function of Police Language from the Perspective of Its Users]. Naše řeč, 101(1), pp. 17-27.

Radk ová Lucie, Mádrová Jarmila. Militärische Missionen in Kriegsgebieten: Funktionen milieuspezifischer Wortschätze. Die Welt der Slaven. Currently in the review process.

Š tr o b 1 Daniel. (2018). Psychologické aspekty zabití [Psychological Aspects of the Act of Killing]. Praha: Triton.

T a y 1 or E. Kelly. (2010). America's Army and the language of grunts: understanding the army lingo legacy. Bloomington: AuthorHouse.

Tuzzi Arjuna, Popescu Ioan-Iovitz, Altmann Gabriel. (2010). Quantitative Analysis of Italian Texts. Lüdenscheid: RAM-Verlag. 